\title{
An Analysis of Sharia and Conventional Shares' System at Indonesia Stock Exchange
}

\author{
Hersugondo Hersugondo ${ }^{1 *}$, Cholimatul Sadiyah ${ }^{2}$, Eka Handriani ${ }^{3}$, Herry Subagyo ${ }^{4}$, Sih \\ Darmi Astuti ${ }^{4}$
}

${ }^{1}$ Diponegoro University, Semarang, Indonesia, ${ }^{2}$ Independent, ${ }^{3}$ Darul Ulum Islamic Centre Sudirman University, Ungaran, Indonesia, ${ }^{4}$ Dian Nuswantoro University, Semarang, Indonesia

There are lots of alternative investing. It is started from investment real assets, securities, from conventional and manifold sharia. Islamic Capital marketand conventional have some type securities which haverisk level of risks. A stock is one of securities among other securities that have the high level of risk. One of the risks that exists in the stock is fluctuations price, it is commonly called as volatility. The aim of this research is to identifiyin Indonesia Stock Exchange (BEI) by using Jakarta Islamic Indekx (JII) and LQ45 Indeks variabels. In our research, we use time sestarted on 1 January 2015 to 10 October 2016 from yahoofinance withARCH/GARCH and EGARCH models processed by Eview 8 . Bfstock JII lower, 0,075 than LQ45 0,0316. If volatility is higher, it means the stability degree lower. Both of those stocks are dominatedLQ45. The third finding is the JII forecasting results through EGARCH hasrefrection proportion JII has smaller 0,194 than LQ45 0,678. It means that JII volatility is lower than LQ45.

Keywords: Volatility, GARCH / EGARCH, Asymmetric Information

OPEN ACCESS

ISSN 2503-3077 (Online) (online)

ISSN 2503-3077 (print)

${ }^{*}$ Correspondence:

Hersugondo Hersugondo hersugondo@/ecturer.undip.ac.id

Received: 21 February 2020 Accepted: 21 March 2020

Published: 30 April 2020

Citation:

Hersugondo H, Sadiyah C, Handriani E, Subagyo $H$ and Astuti SD (2020) An Analysis of Sharia and

Conventional Shares' System at

Indonesia Stock Exchange.

Perisai : Islamic Banking and

Finance Journal. 4:1.

doi: 10.21070/perisai.v4i1.228 


\section{INTRODUCTION}

One of the important decisions faced by investors in choosing an investment is the decision to invest with the sharia and conventional system. As it is sated by Lestari (2013), the decision to invest in the capital market is caused by three factors: firstly, the capital market is an alternative way of funding besides banking. Secondly, the capital market allows investors to have a variety of investment options that suit with their risk perferences. Thirdly, investment in securities has a high liquidity to enable efficient allocation of funds. There are two things that are important for investors to invest in stocks, i.e. returns and risks. Investors, generally, want maximum returns with minimum risk Nastiti et al. (2012) . Every area of investment must have some risks as well as in buying shares. The risks faced in buying stocks are the declining prices (capital loss) and the risk of liquidation of companies issuing these shares. According to Maskur (2009) investors are categorized in three types, first investors who dare to take risk, being called as risk lover / risk seeker. Second, investors who are afraid or reluctant to risk, can be called risk avertor or risk aversion. At last, investors who are not afraid of risk risk moderate / moderate investors or indifference investors.

Along with the ease of investing these days, investors are free to choose to invest using sharia system as well as conventional system. Capital markets, both syariah and conventional trade several types of securities that must have different levels of risk. Investment is a fund commitment with a definite amount to earn uncertain returns in the future Lestari (2013). The fundamental difference in the syariah capital market from conventional capital market is all shares listed on the stock with the disregard of "halal", forbidden and "haram", unforbidden aspects. In a conventional index, the most of important thing is that the listed companies where it suits to the legal system. Thus, if there is an issuer that sells thier shares in a stock exchange in a business sector that is contrary to Islam, that case case is not something shoule be date based over it Sutedi (2011).

Beik et al. (2014) argues that the emergence of sharia products in the capital market originally stemmed from the desire to accommodate the needs of Muslims who want to invest with the principles of sharia. Alsom, this system is grounded by PT Danareksa Investment Management to launch Danareksa Syariah on July 3, 1997. Later in 2000 at the same date, the Indonesia Stock Exchange in cooperation with PT Danareksa Investment Management launched the Jakarta Islamic Index (JII). This proves that the sharia stock system has been accepted in various circles.

The results from the previous research, there are several studies that show the research gap of research conducted by Mukmin and Firmansyah (2015) conducting a study on the volatility of JCI and JII price index with GARCH model with the proportion of 0.05 IHSG and 0.04 JII. It means that the volatility JCI risk is higher than JII. Although the same use of ARCH / GARCH model is different from the research conducted Maskur (2009) that the index of sharia stocks with con- ventional stock index have no changing even JII experienced a drastically decrease in 2009. With regard to capital or sharia capital markets, almost all investors are already aware that they should consider risks in making investment choices. And every investor who invests shares has two possibilities of getting capital gains and dividends or otherwise experiencing capital loss and not getting dividends.

Therefore, this study will observe and calculate the risks that occur in the stock market of sharia and conventional stock market by applying the applicative alternation of Autoregressive Conditional Heteroschedasticity $(\mathrm{ARCH})$, Generalized ARCH (GARCH) and Exponential GARCH (EGARCH). From the phenomenon and research gap above, we are interested to analyze the risk between sharia and conventional stock. This study aims to measure the risk of sharia and conventional stock shares and to measure the accuracy of forecasting sharia and conventional stock shares.

\section{LITERATURE REVIEWS}

\section{Capital Market as an Alternative Way of Investment}

The capital market is a market for various long-term financial instruments that can be traded, whether bonds, equities, mutual funds, derivative instruments or other instruments. The capital market becomes a means of funding for companies and other institutions. Funds obtained from the capital market can be used for business development, exapansion, an additional capital working, etc. Capital market also a means for people to invest. Thus, the public can place the funds they have in accordance with the characteristics of profit and risk of each Maskur (2009). According to Soedewi and Purqon (2015) the capital market is one of the most important instruments for a country's economy. The attractiveness of the capital market for the economy of a country is as an alternative way to collecting funds other than banking and commodity exports. In addition, the capital market allows market players who act as investors to have a variety of investment options in accordance with their risk choices.

Every investor has the same goal in investing to get capital gains and dividends but investors also get a loss (capital loss). Viewed from the willingness to bear the risk, investors are categorized into three types namely; firstly, investor who dare to take risk or being called as risk taker / risk lover / risk seeker. Secondly, investors who dare to take risks, commonly called risk avert or risk aversion. Thirdly, investors who are not afraid nor dare to take the risk, being called as risk moderate investor or indifference investor. Along with the economic development of a country, there is a tendency of the community to be braver to take risks because it promises higher returns, high risk high return, and low risk low return. Therefore, the role of banks in mobilizing funds is decreasing followed by the increasing role of the capital market in mobiliz- 
ing public funds into the productive sector, known as financial market disentermediation.

\section{Conventional}

The conventional capital market is an organized financial system, including commercial banks and financial intermediaries, and all outstanding securities. In a narrow sense, the capital market is a market that is used to trade stocks, bonds, and other types of securities using the services of stock brokers Sunariyah (2004). In the conventional index, all stocks listed in the stock disregard the "halal-haram" or forbidden and unforbidden aspects and importantly listed companies are already legally consequential as it is not an issue if there is an issuer that sells thier shares in a stock exchange in a conflicting business sector with Islam Sutedi (2011). The mechanism of conventional capital market transactions using the concept of interest containing usury, contains transactions that are speculative and manipulative. And in conventional capital markets, investors can buy or sell shares directly by using the services of brokers. This situation allows for speculators to play the price easily.

The provides the understanding of capital markets which thes rpublic offering and trade, public companies relatedA capital markets includess traded such as stocks, bonds, warrants, rights, and derivative productsconvertibbonds, futures, forwards and swaps. While on the money market, treasure.

\section{Sharia}

Capital market is a capital market that is run by the principlesce with Islamic Sharia (Sutedi,pital market is an activity concerned with the public offeriof securities trading, publiclylisted securities-rcompanies, and sharia institutions are principles based on Islamic teachings established by the DSNMUI, both established by this fatwaI /andinvestment that are in accordance with Islamic teachings. Insence,ements:irsTypes of business, goods, services and contracts and the management of issuers or public companies issuing sharia securities shallTconduct oftransactions shall be in accordancwith the principle of prudence and shall not be allowed to speculate and manipulate which contains the elements of Dharar, Gharar, Riba, Maisivice, and Cruelty Kurniawan et al. (2014).

\section{The Risk of Share Market}

\section{Return}

In doing investment, an investor would expect a certain rate of return in return for taking certain risks. In general, profits derived from stocks are capital gains that is the difference between the selling price and the purchase price and from the dividend distributed by the company. Also there are som companies no to share their dividends.

\section{Risk}

Risk can be interpreted as a storage between expected returns and actual returns. There are two measures used to measure risk: standard deviation and stock beta. The standard deviation describes the stock return fluctuation and the average return. The fluctuation of return can be positive, that is below the average return Samsul (2006).

\section{Volatility}

Volatility means conditional variance is a statistical measure that indicates the magnitude of fluctuations in the price of a security or a commodity within a given period of time. The volatility of the stock price return represents the risk of returning the stock's price, in other words, the higher the level of uncertainty of stock returns can be attributed to higher volatility, volatility comes from volatile words which refers to conditions that have unstable connotations, tend to vary, and are difficult to estimate.

\section{Review of The Previous Research}

This research refers to previous research, to simplify, data collection, data analysis, and data processing. As for some previous research is as follows: Maskur (2009), indicated that the conventional stock index with the sharia stock index has no difference that stands out. This is evident from their performance in the form of an index growth trend that both declined, even JII experienced a more drastic decline in 2009. Mukmin and Firmansyah (2015), showed that the volatility of JCI is higher than JII. But if judging from its accuracy, JII is more accurate than JCI. Hasbullah et al. (2013), showed that the best performing Shariah stock for five-step forecasting according to Sharpe's Measure is INTP shares. Kurniawan et al. (2014), showed that the performance of sharia stock index performs better than conventional stock index performance. Lestari (2013), showed that there is no difference of risk between sharia and conventional stock but from the level of returns on syariah stock, it is higher than the return rate on conventional stock. Rosyida and Mawardi (April 2015), showed that the return and risk level of sharia and non-syariah stocks is equals and has no significant difference, meaning that the return and risk generated by both stocks are the same. Fadillah and Nur (2010), showed that the return rate of sharia shares (JII) is better than conventional stock (LQ45). Widuhung and Debyol (2014), suggested that investing in gold is more profitable than investing in sharia stocks because gold returns are higher than sharia stocks and gold risk is lower than sharia stocks. The previous research above becomes a reference for researchers to conduct a further research;

\section{Hypothesis}

The hypothesis is a temporary answer to a research problem whose truth is still to be tested empirically. Hypothesis in this research is as follows: Sharia stock avoids from 
speculative system hence hypothesised that there are risksaria (JII)becomeshigh.

\section{METHOD OF THE RESEARCH}

\section{Object Observation and Data Source}

The data used in this research is secondary data that is quantitative about the closing price index of the stock price index LQ45 and JII. The data source in this study is obtained from $\mathrm{w}$ ww.yahoofinance.co.id while according to the classification of collection, the data used is time seriesto findanges in the past, which can be used to estimate the pattein the future. Considering the relatively stable condition of the capital market, this study uses the period from 01 January 2015-10rogram.

\section{Operasional Definition}

Capital markets or capital market dynamics are measured using JII and LQ45.

1. Volatility is the higher the level of uncertainty of stock returns that can be obtained due to the higher levels of volatility. Volatility is measured using variance from residual squares GARCH and C3 EGARCH.

2. JII index is an index containing 30 stock companies that meet the investment criteria based on Islamic sharia

3. The LQ45 index is the market capitalization value of the 45 most liquid stocks and has a large capitalization value. This is an indicator of liquidation.

\section{Analysis Method}

\section{Unit Root Test}

Stasioneritas is one of the important requirements in econometric model for time series data. Stationary data are data that show the mean, variance and autovarians (at lag variations) remain the same at any time the data is formed or used, meaning that the stationary data of the time series model can be said more stabil. One of the formal concepts used to determine the stationarity of data is through unit root test. This test is a popular test developed by David Dickey and Wayne Fuller as Augmented Dicky-Fuller (ADF). If a time series data is not stationary at zero order, I (0), then the stationerity can be searched by the next order to obtain the stationarity level in the n-th order (fist difference or I (1), or second difference or I (2) and so on Nachrowi and Hardinus (2006).

Some models can be selected to perform the ADF test:

$\triangle \mathrm{Y}_{t}=\delta \mathrm{Y}_{t-1}+\mathrm{u}_{t}$ (without intercept) (3.1)

$\triangle \mathrm{Y}_{t}=\beta+\delta \mathrm{Y}_{t-1}+\mathrm{u}_{t}$ ( with intercept) (3.2)

(3.3)

$\triangle \mathrm{Y}_{t}=\beta_{1}+\beta_{2-t}+\delta \mathrm{Y}_{t-1}+\mathrm{u}_{t}$ (intercept with time trends)

$$
\triangle=\text { first difference of the variable used }
$$$$
\mathrm{t}=\text { time }
$$

\section{ARCH Model}

$\mathrm{ARCH} / \mathrm{GARCH}$ is a forecasting time series model used in single equation meaning it uses one variable only. By using the data period information where then can predict the value or data for the period to come. ARCH / GARCH is usually used to find the volatility of a data. What is seen is the effect of variance and quadratic error from the data series. To overcome the variant and dependent variance and the ARCH model developed by Engle (1982) will be used. The model is formulated as follows:

$$
\begin{aligned}
& \mathrm{y}_{t}=\mathrm{I}_{t} \gamma+\varepsilon_{t}(3.4) \\
& \sigma_{t}^{2}=\omega+\sigma \varepsilon_{t-1}^{2}
\end{aligned}
$$

The mean Equation in equation (3.4) is written as a function of exogenous variables, (It), and error term $\varepsilon$. For the second equation $\sigma 2$, is the variance error, $\varepsilon$ is the error term, $t$ is time. Of course, the variance error depends not only on one lag term of the quadratic term error but it can be more than one quadratic term error.

\section{GARCH M odel}

One of the most populars is the GARCH model developed by Bollerslev in H. Hersugondo. et.al. (2015); H. Hersugondo, et.al. (2016). The simplest GARCH model often used by GARCH $(1,1)$ is formulated as follows:

$$
\begin{aligned}
& \mathrm{y}_{t}=\mathrm{I}_{t} \gamma+\varepsilon_{t} \\
& \sigma_{t}^{2}=\omega+\sigma \varepsilon_{t-1}^{2}+\beta \sigma_{t-1}^{2}
\end{aligned}
$$

The mean Equation in equation (3.6) is written as a function of exogenous variables, (It), and error term. Equation (3.7) refers to the variance forecast of the period ahead $\sigma_{t}^{2}$ and $\sigma_{t}^{2}$ and is a function of the average variance $(\omega)$, (news) issues concerning the volatility of the previous period, measured as the lag of the square residual of the mean equation $\sigma \varepsilon_{t-1}^{2}$ (the ARCH term), and the past variance $\sigma \varepsilon_{t-1}^{2}$ (the GARCH term).

\section{EGARCH Model}

The limitations of the ARCH and GARCH model specifications are the shock of symmetrical volatility. Often the asymmetrical effect occurs, i.e. when the effect on volatility is different between good news and bad news cases occur. This asymmetry occurs when the downward movement in the capital market is followed by a higher volatility than the upward movement of the same direction. In other words, good news and bad news do not have the same effect on stock return volatility. The effect on volatility from bad news in the coming period is greater than the effect of good news in the coming period. The EGARCH or Exponential GARCH model $(1,1)$ was developed by Nelson (1991) in Anton (2006). The model is formulated as follows:

$$
\begin{gathered}
\log \left(\sigma_{t}^{2}\right)=\alpha+\beta \log \left(\sigma_{t-1}^{2}\right)+ \\
\alpha\left(\left(\frac{\varepsilon_{t-1}}{\sigma_{t-1}}\right)-\sqrt{\frac{2}{\pi}}\right)+\gamma \frac{\varepsilon_{t-1}}{\sigma_{t-1}}
\end{gathered}
$$




\section{RESULT OF THE RESEARCH}

[Table 1 about here.]

JII and LQ45 stock price data shows non-stationary data distribution. Stationary is measured from data distribution not affected by constant, trend and past period. To convert non stationary time series data into stationary can be done by lowering the level to first difference level. The level of changes at JII and LQ45 means return. When the variable is converted to return, the return variable indicates a stationary phenomenon. Then the return data JII and LQ45 can be analyzed using ARCH.

\section{ARCH Model}

JII and LQ45 stock price data was detected that there is ARCH phenomenon that contains autoregressive and heteroxedasticity. After the change to the level of JII and LQ45, data does not contain data autoregressive and heteroxdascisity. It can be seen from the graph. Here, based on ARCH study, then the calculation is faced with GARCH and EGARCH.

[Figure 1 about here.]

[Figure 2 about here.]

[Figure 3 about here.]

[Figure 4 about here.]

[Table 2 about here.]

GARCH is used to measure the volatility of a data, RESID (-1) $\wedge 2$ coefficient indicates that JII 0.110 volatility is lower than LQ45 0.186. GARCH (-1) coefficient illustrates that the higher the volatility the slower the stability level as well as the lower the volatility the faster the level of stability. The coefficient JII is higher that is 0.762 compared to LQ45 is 0.650 , so the stability level JII is faster than LQ45. EGARCH is used to measure the volatility of a data and symmetric symmetry between bad news and goodnews. C (3) coefficient illustrates that JII volatility is lower that is 0.075 compared to LQ45 that is 0.316 . $\mathrm{C}$ (4) coefficient to test the asymmetric nature of information, if the negative sign (-) shows the effect of bad news information stronger influence than good news. So, the effect of bad news JII is lower $-0,060$ compared to LQ45 $-0,085$, meaning if it is responded negatively, the impact to risk volatility is higher than the news that responded positively. C (5) coefficient illustrates that the higher the volatility then the slower the stability level, JII of 0.970 compared to LQ45 of 0.812 . This means that the stability rate JII faster than LQ45.

AIC (Akaike info criterion) and SC (Schwarz criterion) are used to select the best model to measure volatility between GARCH and EGARCH. The best model chosen to measure both JII and LQ45 volatility is EGARCH. Although the coefficient of AIC GARCH JII 6,983 and SC 7.019 while AIC LQ45 7,393 and SC LQ457,430 compared to AIC EGARCH JII 6,984 and SC 7,030 while AIC LQ45 7,398 and SC LQ45 7,443 is dominant which is almost the same in its lowest value but EGARCH can give more information and more complete, which has information about volatility and asymmetric effects occurs when the effect on volatility is different between good news and bad news cases. While GARCH can not distinguish good news and bad news.

Why JII shares are more stable than LQ45. JCI is all stocks that exist in the Indonesia Stock Exchange so many speculators (someone who is looking for profits from the difference in trade prices) play in JCI. So IHSG and LQ45 have a high risk, IHSG first then followed by JCI which is lowered to LQ45 consisting of 45 large capitalized indices, fewer speculators than IHSG. Then LQ45 is down again to JII which consists of 30 stocks that have met the criteria of Islamic Sharia. Thus, it is alleged that fewer speculators in JII than LQ45 then it makes JII has no more risky than LQ45.

\section{Forecasting}

Forecasting needs to be used to support that JII is less volatile than LQ45 and to take the necessary yet strategic steps to avoid risk of loss. The choice of forecasting model also needs to be very important because each data type has different model. After determining the best model, the model selected is EGARCH model. Here is the forecasting result obtained from the e-views program;

[Figure 5 about here.]

[Figure 6 about here.]

Forecasting JII and LQ45 show the upcoming variants of JII and LQ45 on stock prices. By using this EGARCH model, it can be seen from both graphs that the potential of price risk is constantly changing and fluctuating. If seen from the proportion of bias, there is a difference between JII and LQ45. Where the proportion of bias for JII is smaller that is 0.000194 while the proportion of bias for LQ45 is 0.000678 . This means by using the EGARCH model, LQ45 stock prices have a higher proportion of forecasting bias. It indicates LQ45 volatility is higher than JII volatility. The proportion of LQ45 bias is also supported by RMSE. If seen from Root Mean Squared Error LQ45 it is equal to 10.05049 while JII is 8.053052 .

\section{CONCLUSION}

\section{Conclusion}

Based on the results of research conducted in stocks JII and LQ45 in Indonesia Stock Index in the period 2015-2016, it can be concluded that: 
1. Having hthan JII based on GARCH and EGARCH measurements.

2. Bad News and Good News volatility sourced from good and negative news, negative news is more dominant influence share price in LQ45 than JII.

3. Lower than LQ45. This metheven though it applies the same technique.

\section{Limitations}

Here are the limitations in this study that need to be noticed by further researchers:

1. Proxy of conventional stock index is not only LQ45 but there

\section{REFERENCES}

Anton (2006).

Beik, I., Syauqi, Fatmawati, S., and Wulan (2014). The Influence of Sharia International Stock Price Index and Macro Economic Variables against Jakarta Islamic Index. Faculty of Economics and Management, vol. VI (Bogor: Bogor Agricultural University).

Fadillah, R. and Nur, F. (2010)

Hasbullah, E., Soeryana, Mohd, I., Bin, Mamat, and Mustafa (2013).

Kurniawan, R., Dwi, and Asandimitra, N. (2014). A Comparison Analysis of Sharia Stock Performance and Conventional Stock Performance. Journal of Management Science 2.

Lestari, A. (2013). A Comparative Analysis of Risk and Return of Sharia Shares and Conventional Shares (Case Study on JII Stock Index and LQ-45 Index) (Riau).

Maskur, A. (2009).

Mukmin, A. and Firmansyah (2015). A Comparative Analysis of Stock Price Index Volume JCI and JII. Journal of Economics and Banking 3, 69-84.

Nachrowi, D. and Hardinus, U. (2006).

Nastiti, K., Ayu, S. L., and Agus (2012). A Volatility Analysis Company Shares Go Public with ARCH-GARCH Motion. A Journal of Science and Arts. Faculty of Mathematics and Natural Sciences. Sepuluh Nopember Institute of Technology (ITS) 1, 2301-928. are other indexes such as JCI, Compass 100 and others. Likewise proxy syariah index is not only JII but also there Indonesia Shariah Stock Index (ISSI).

2. Stock index movement is allegedly not only caused by internal factors of the stock market but it can also be caused by many factors from outside such as politics, labor market, goods market, international market, macro market and so on.

\section{Research Implications}

Based on the findings of this study, the suggestion that can be given is that, it hopes the next researchers not only use univariate (one variable) but also use multivariate EGARCH approach.

Rosyida, A. G. and Mawardi, I. (April 2015). The Comparison of Return, Risk and Coefficient of Variance on Sharia Shares and Non-Sharia Shares in Indonesia Stock Exchange (IDX) Period 2011-2013 2.

Samsul, M. (2006). Capital Market and Portfolio Management (Jakarta: Erlangga). Soedewi, S. and Purqon, A. (2015).

Sunariyah (2004).

Sutedi, A. (2011). Pasar Modal Syariah. Cet. 1. Jakarta: Sinar Grafika.

Widuhung, S. and Debyol (2014). The Comparison of Return and Investment Risk on Sharia and Gold Shares. Journal of Al-Azhar Indonesia Series of Social Institutions 2 .

Conflict of Interest Statement: The authors declare that the research was conducted in the absence of any commercial or financial relationships that could be construed as a potential conflict of interest.

Copyright (c) 2020 Hersugondo, Sadiyah, Handriani, Subagyo and Astuti. This is an open-access article distributed under the terms of the Creative Commons Attribution License (CC BY). The use, distribution or reproduction in other forums is permitted, provided the original author(s) and the copyright owner(s) are credited and that the original publication in this journal is cited, in accordance with accepted academic practice. No use, distribution or reproduction is permitted which does not comply with these terms. 


\section{LIST OF TABLES}

$1 \quad$ Unit Root Test $\ldots \ldots \ldots \ldots$ 


\section{TABLE 1 | Unit Root Test}

\begin{tabular}{|c|c|}
\hline ADF (Augmented Dickey Fuller ) & $\begin{array}{l}\text { Variabel } \\
\text { JII }\end{array}$ \\
\hline \multicolumn{2}{|l|}{ Level } \\
\hline 1. Intercept & 0,6353 \\
\hline \multicolumn{2}{|l|}{0,5407} \\
\hline 2. Trend and Intercept & 0,8701 \\
\hline \multicolumn{2}{|l|}{0,8615} \\
\hline 3. None & 0,7439 \\
\hline \multicolumn{2}{|l|}{0,6873} \\
\hline \multicolumn{2}{|l|}{$1^{s t}$ difference } \\
\hline 1. Intercept & 0,0000 \\
\hline \multicolumn{2}{|l|}{0,000} \\
\hline 2. Trend and Intercepet & 0,0000 \\
\hline \multicolumn{2}{|l|}{0,000} \\
\hline 3. None & 0,0000 \\
\hline
\end{tabular}


TABLE 2 | GARCH and EGARCH Test Variance Equation

\begin{tabular}{|c|c|c|c|}
\hline Variabel & GARCH & & $\overline{E G A R C H}$ \\
\hline variabel & D JII & D LQ45 & D JII \\
\hline+$) \mathrm{D}$ & & & \\
\hline LQ45 & & & \\
\hline C & 8,346 & 17,648 & - \\
\hline+$)-$ & & & \\
\hline & $(0,025)$ & $(0,000)$ & - \\
\hline+$)-$ & & & \\
\hline $\operatorname{RESID}(-1)^{\wedge} 2$ & 0,110 & 0,186 & - \\
\hline+$)-$ & & & \\
\hline & $(0,038)$ & $(0,000)$ & - \\
\hline+$)-$ & & & \\
\hline GARCH $(-1)$ & 0,762 & 0,650 & - \\
\hline+$)-$ & & & \\
\hline & $(0,000)$ & $(0,000)$ & - \\
\hline+$)-$ & & & \\
\hline $\mathrm{C}(2)$ & - & - & 0,067 \\
\hline+$) 0,614$ & & & \\
\hline & - & - & $(0,260)$ \\
\hline+$)(0.003)$ & & & \\
\hline $\mathrm{C}(3)$ & - & - & 0,075 \\
\hline+$) 0,316$ & & & \\
\hline & - & - & $(0,012)$ \\
\hline+$)(0,000)$ & & & \\
\hline $\mathrm{C}(4)$ & - & - & $-0,060$ \\
\hline+$)-$ & & & \\
\hline 0,085 & & & \\
\hline & - & - & $(0,003)$ \\
\hline+$)(0,030)$ & & & \\
\hline $\mathrm{C}(5)$ & - & - & 0,970 \\
\hline+$) 0,812$ & & & \\
\hline & - & - & $(0,000)$ \\
\hline+$)(0,000)$ & & & \\
\hline ARCH-LM Test & 1,526 & 0,786 & 3,080 \\
\hline+$) 0,310$ & & & \\
\hline & $(0,217)$ & $(0,375)$ & $(0,080)$ \\
\hline+$)(0,580)$ & & & \\
\hline $\mathrm{AlC}$ & 6,983 & 7,393 & 6,984 \\
\hline+$) 7,398$ & & & \\
\hline SC & 7,019 & 7,430 & 7,030 \\
\hline+$) 7,443$ & & & \\
\hline
\end{tabular}




\section{LIST OF FIGURES}

$\mathrm{JII} \ldots \ldots \ldots \ldots \ldots \ldots \ldots$

$\mathrm{D}(\mathrm{JII}) \ldots \ldots \ldots \ldots \ldots \ldots$

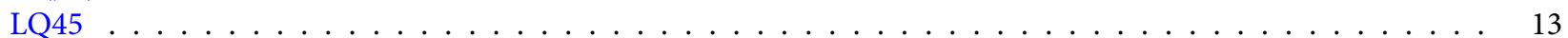

$\mathrm{D}(\mathrm{LQ} 45) \ldots \ldots \ldots \ldots \ldots \ldots$

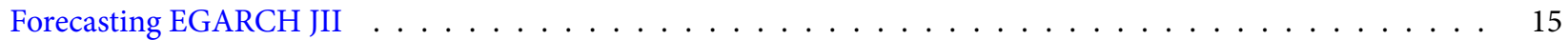

Forecasting EGARCH LQ45 . . . . . . . . . . . . . . . . . . . . . . . . . 16 


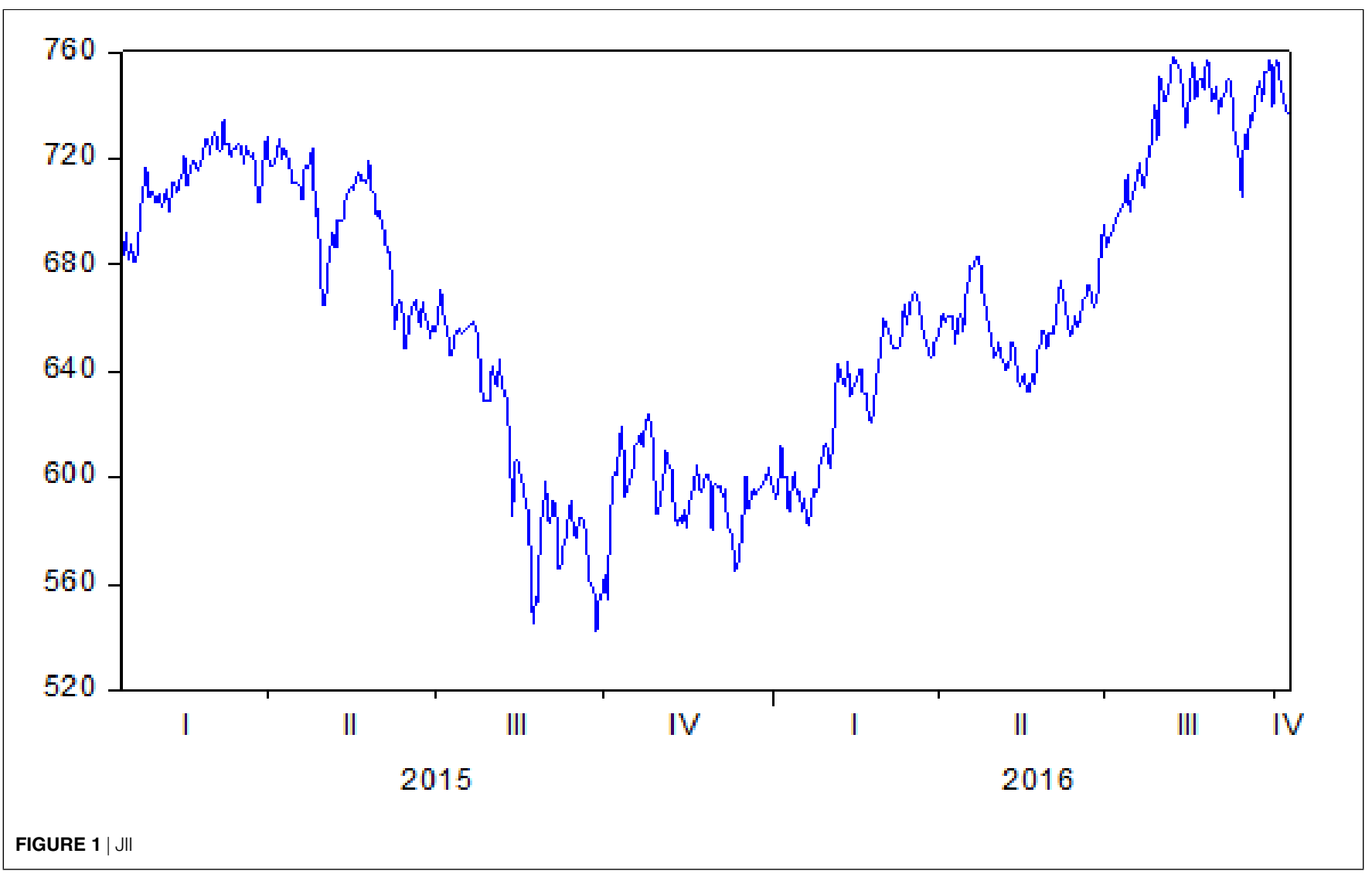




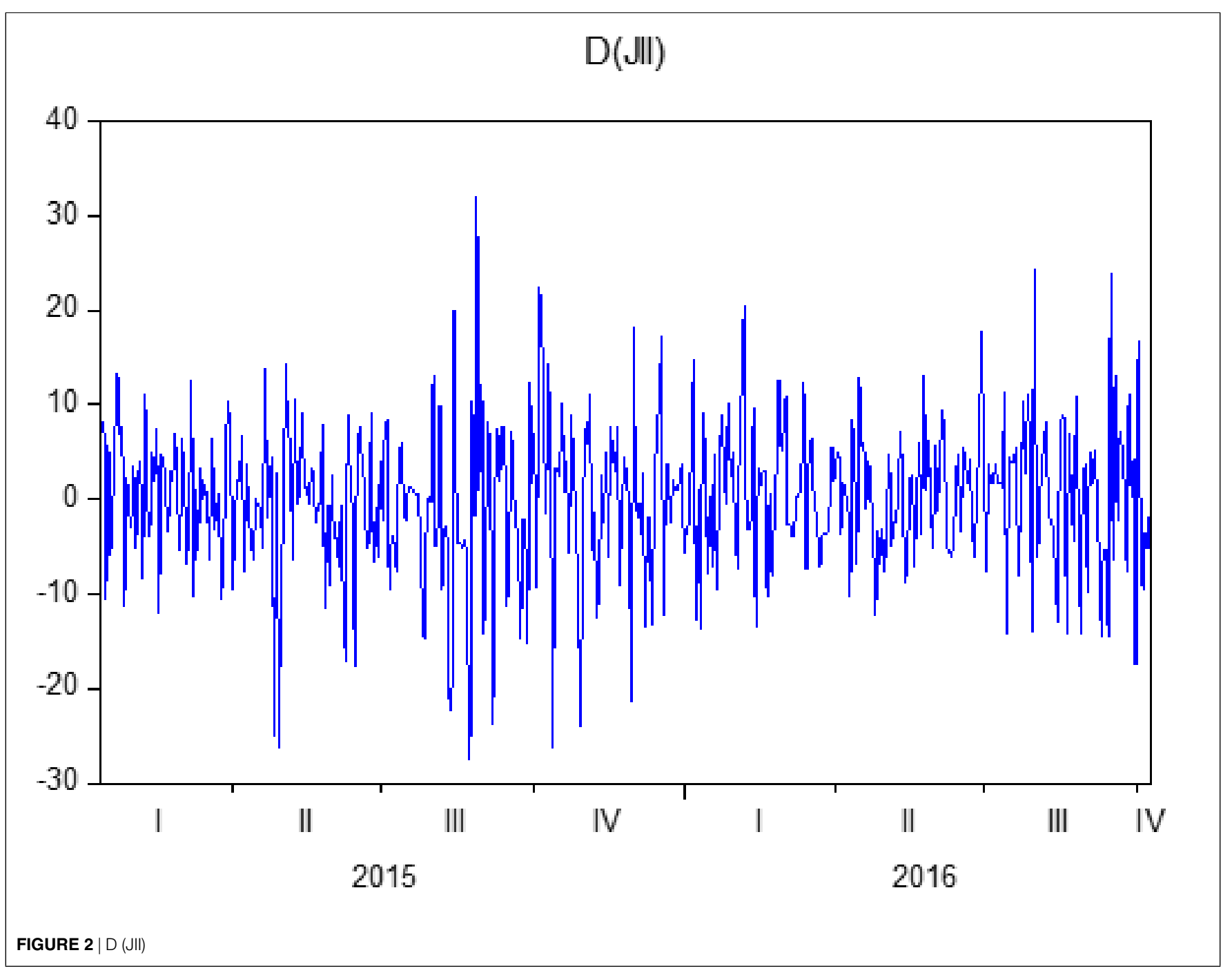




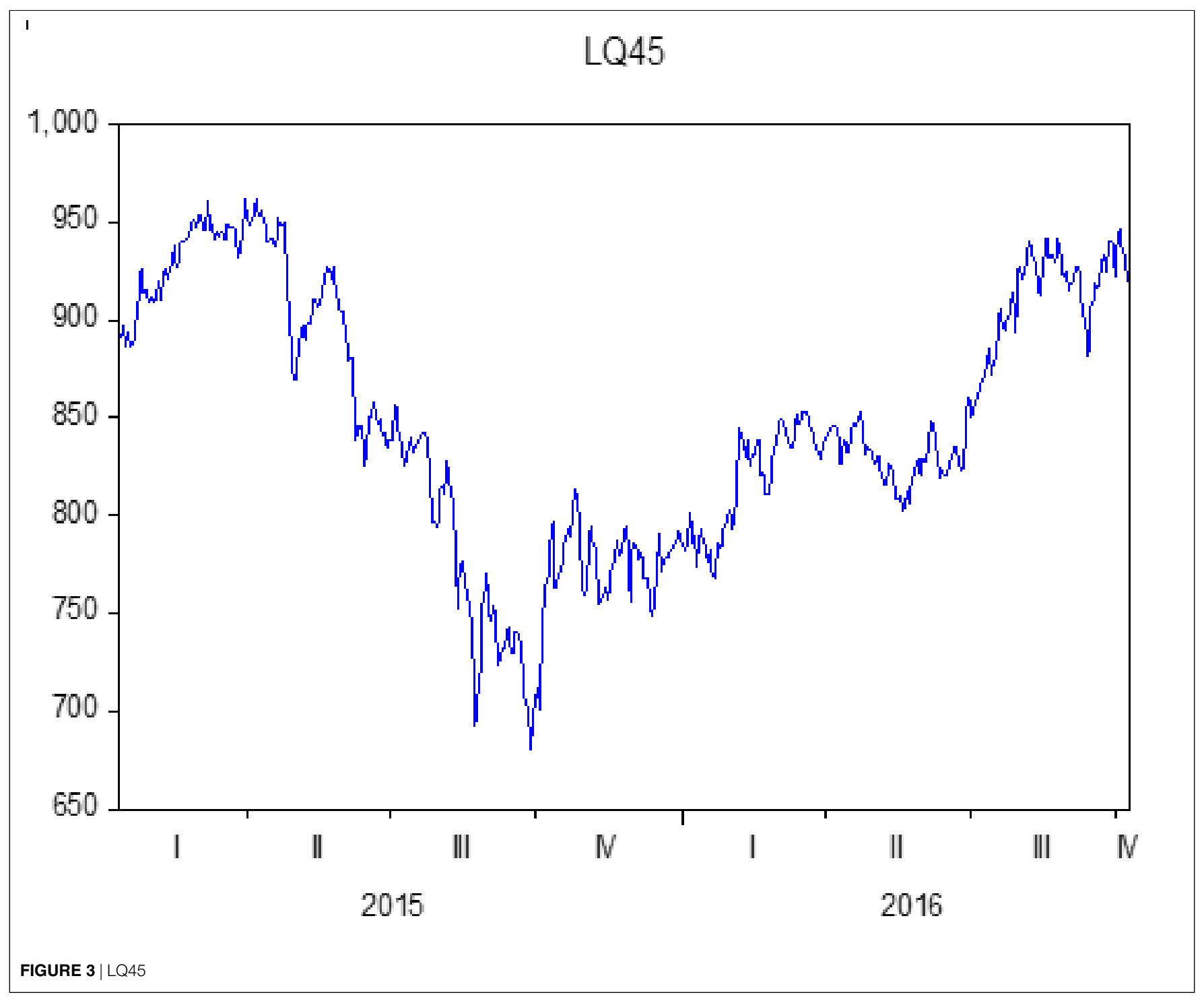




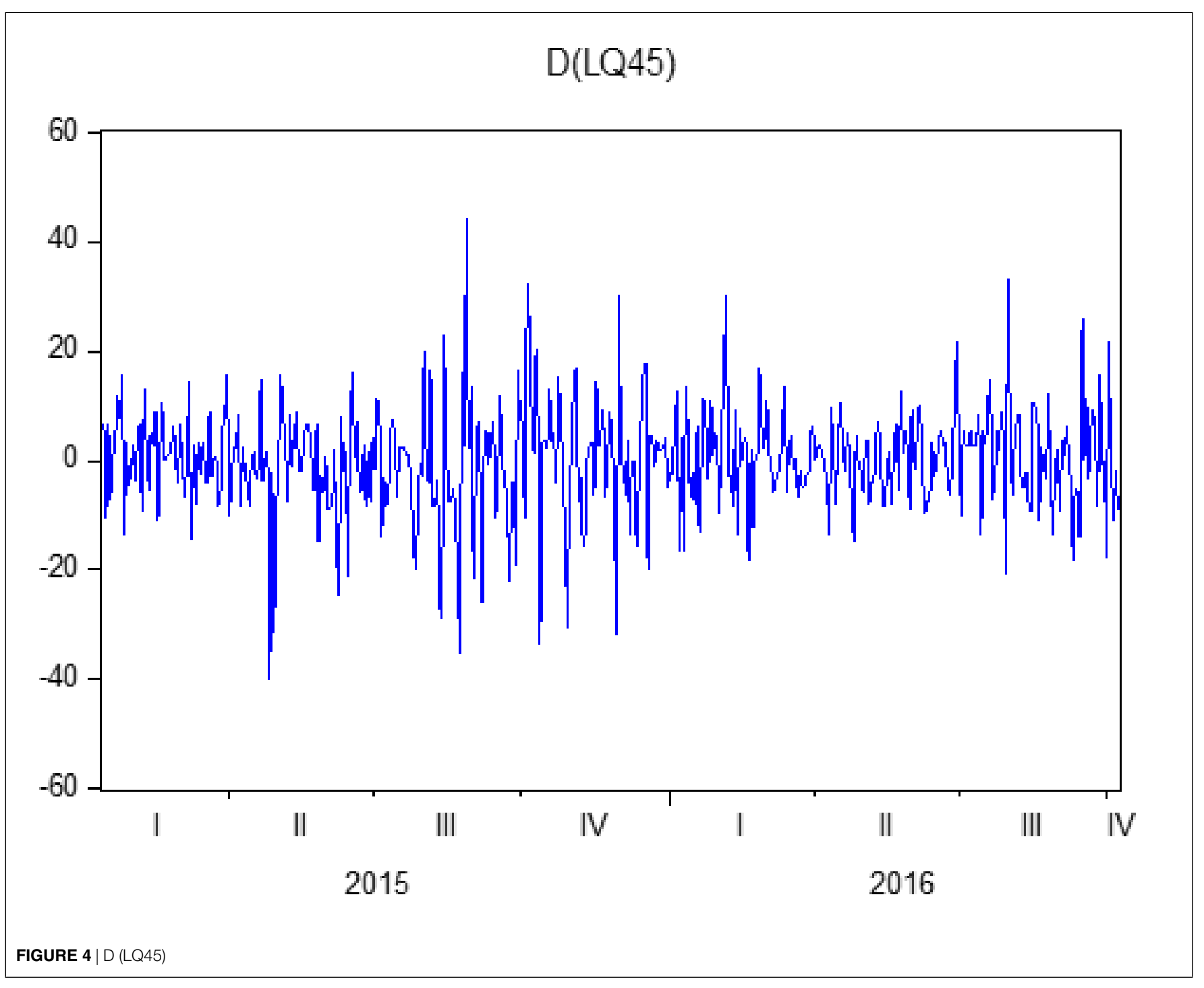



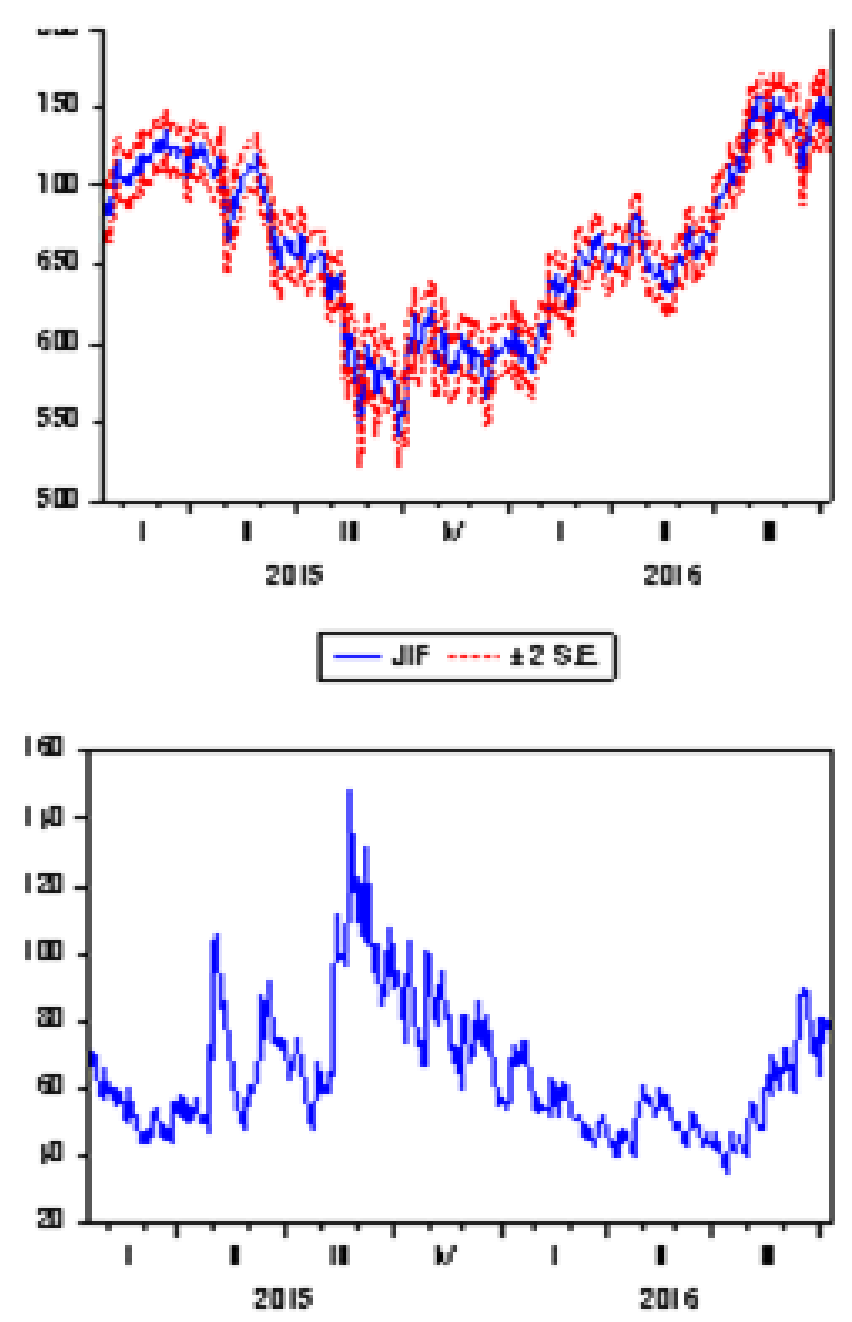

Fon cas lorvartana

Forecast: JIF

Actal: JI

Forecast sample: $1 / 12 / 2015$ 10/10/2016

Ad usted sample: $1 / 13 / 2015$ 10/10/2016

Include d obse urtions : $\mathbf{4 5 5}$

Root the al Squared Emor 8053052

Meal Absolut Emor 6059063

Mear Abs. Perce it Emor O991250

The il lnequa ity Coefficie ot OD06069

$B$ ies P roportion

0000194

U'ariance Proportion

0000168

Courial ce P roportion

0.999641

FIGURE 5 | Forecasting EGARCH JII 

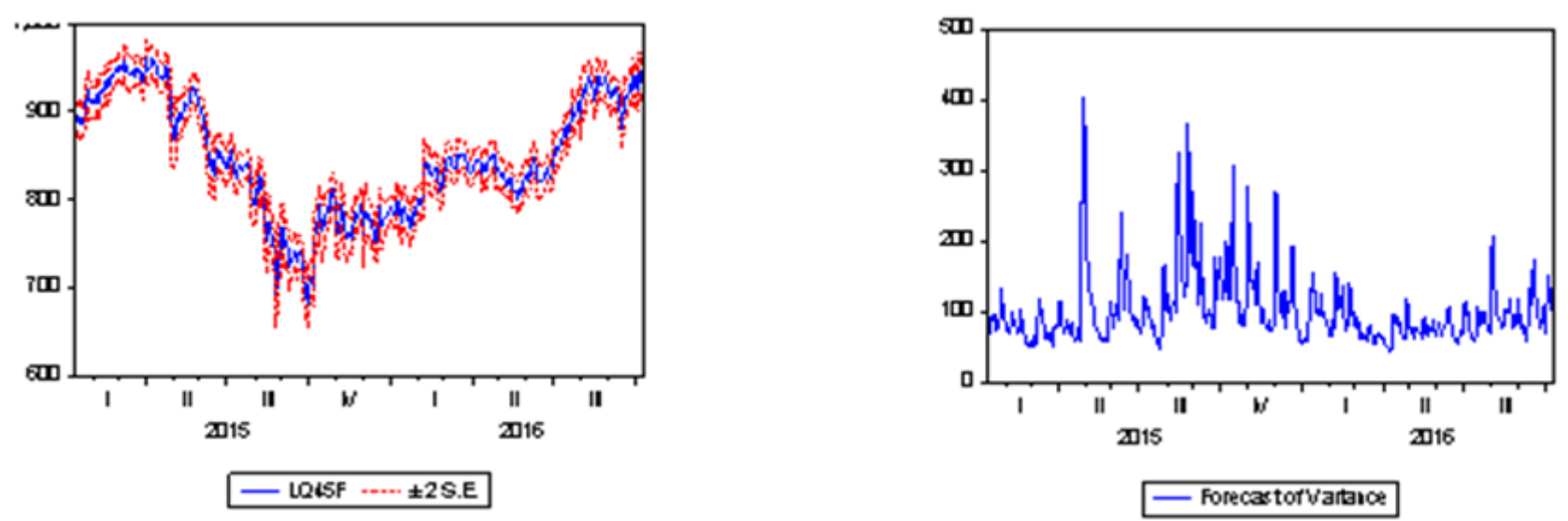

Forecast: LQ45F

Actua: $\operatorname{LQ45}$

Forecast sample: $1 / 12 / 201510 / 10 / 2016$

Adusted sample: $1 / 13 / 201510 / 10 / 2016$

holuded obsengtions: 455

Root Mulan Squared Error 10.05049

Mulean Absolute Error $\quad 7.328816$

Mulean Abs. Percent Eror 0882669

Theil hequality Coefficiert 0005909

Bias Proportion 0000678

Variance Proportion 0000028

Coveriance Proportion 0.999294

FIGURE 6 | Forecasting EGARCH LQ45 